\title{
THE POLITICAL IMAGE OF GHANAIAN CIVIL SERVANTS
}

\author{
By Rolf Hanisch
}

\section{POSITION AND FUNCTION OF THE CIVIL SER VICE}

In African countries, the civil service represents a social class of considerable importance which surpasses by far its numerical strength. For the success of the Politicians' policy depends largely on its efficiency and its subjective consciousness of wanting to prepare and implement a certain policy. There where the state tries moreover to take an active hand in the development process by planned interventions and measures as well as by monopolization of or partnership in further social and economically productive sectors, its importance is due to increase even more.

But, in the context of their societies, the civil servants represent most of ten a socially privileged group which would be likely to succeed in supplanting the foreign (colonial) officers and in taking possession of their benefits. As the state activities were extended, their number increased considerably. In Ghana, they increased tenfold in about two decades.

Table 1: Civil servants entitled to a pension in Ghana

\begin{tabular}{|c|c|c|c|}
\hline & & Ghanaians & Foreigners \\
\hline 1952 & & $520(28 \%)$ & 1.322 \\
\hline 1957 & & $1.581(58 \%)$ & 1.138 \\
\hline 1961 & & $2.883(97 \%)$ & 66 another 660 \\
\hline 1970 & about & 5.000 & on contract \\
\hline
\end{tabular}

Source: Ghana Parliamentary Debates, Vol. 23

26. 5. 1961 , c. 1010

Civil Service List 1969/1970

On account of their privileged position, of their training in western metropoles and at local institutes with "western" curricula, in short, of their assimilation of the western way of life, they often have the reputation of being "neo-colonialists" or, at least, not particularly innovatory in their attitude.

Nkrumah, for example, asserted after his fall, that the civil service also had sabotaged his socialist programme $e^{1}$. At the time, some people had even to follow courses at his Ideological Institute in Winneba. However, the military/police regime, the NLC, which raised a revolt against him, managed without numerous dismissals in the civil service which became even one of its important supporters.

It was first the civil government of Busia, which succeeded the NLC, which dismissed, upon entering office, 586 civil servants on the grounds that those were "lazy, inefficient and not looking ahead". With this, it brought about the first

1 Nikrumah, Kwame: Dark Days in Ghana (London 1968, p. 65). 
constitutional crisis of the young Second Republic, since the dismissals ensued on a dubious legal basis and were forthwith cancelled by a court of law. These dismissals, the government's ignoring and rebuking the judgement, finally the lack of political dynamic leadership and, lastly, the reduction of some of the expense allowances for civil servants, led to an estrangement from the democratically elected Busiagovernment even by a large part of the justice and of the civil service (besides the army, trade unions, students as well). Thus, it created a climate in which it seemed possible to the army again to seize power by a coup d'état.

\section{METHOD AND TARGET GROUP OF THE INTERVIEW}

Toward the middle of the "Second Republic" in Ghana (in December 1970/ January 1971), the author conducted an interview among the middle class and higher civil servants (defined according to an annual income of more than $1400 \mathrm{NC}$, with reference to the Civil Service List of 1969/70) about their political image. The core of the series of problems concerned were the economic and development problems and prospects of the country under particular consideration of international relations. Of course, such an interview can hardly be conducted in Africa according to the socio-scientific criteria which are necessary and usual in the North Atlantic region. Alone the permission for such an enterprise is difficult enough to obtain, but, in this case, was obligingly delivered by the Secretary of the Cabinet.

$\mathrm{He}$ also offered his kind help for the distribution and collection of the questionaires.

It was understood that no questions concerning the specific, actually controversial political arguments - such as the country's policy concerning South Africa would be set. On the other hand, the anonymity of the answer and the return of the questionaires in sealed envelopes were to guarantee an unbiassed statement.

About 1400 questionaires (toward a target group of 5000) were distributed (approximately 900 in Accra, 500 in the provinces). 237 were filled in and returned, 107 from Accra, 130 from the provinces.

Table 2: Personal Statements of Respondents

\begin{tabular}{lclcl}
\hline Ministry: & & & \\
Education & $25 \%$ & Agricultural & $15 \%$ & External Affairs $6 \%$ \\
Finance & $19 \%$ & Labour & $7 \%$ & Others \\
Age: & & Date of joining civil service & \\
$20-40$ & $46 \%$ & & & \\
$41-50$ & $38 \%$ & since $1966:$ & $15 \%$ & \\
$51-60$ & $16 \%$ & $1957-1966:$ & $30 \%$ & \\
& & before 1957: & $55 \%$ & \\
\hline
\end{tabular}


The statement as to the knowledge of languages was also to disclose to which tribe the individuals belonged (if it is assumed that the first language stated is the mother-tongue). Ashantis, Fantis and Gas are overproportionally represented in the sample - as well as in the whole administration - as compared to their proportion in the total population. The cause thereof is not lastly to be found in the different stage of development of the single regions and of their population, but, among other things, also in the knowledge of the English language - which is an absolute prerequisite for a profession in the administration. Whereas, for example, on the average of the country (1960), $17 \%$ of the Ghanaians could, anyhow, write the English language, only $1 \%$ could do so among the populations of the North. Other foreign languages are hardly spoken (among the interviewees only $5 \%$ spoke French, $2 \%$ other languages). But almost everyone mastered two to five Ghanaian languages. Thus, $70 \%$ of the interviewees speak and understand Twi, and more than half of those $\mathrm{Ga}$. The majority of the interviewees would also be in favour of the introduction of a Ghanaian national language (55\% of Akan/ Twi, $5 \%$ of other languages).

Table 3: Knowledge of Languages

\begin{tabular}{lccccc}
\hline & Twi/Akan & Fante & Ga & Ewe & 12 others \\
\cline { 2 - 6 } $\begin{array}{l}\text { 1st language } \\
\text { 2nd language }\end{array}$ & $37 \%$ & $21 \%$ & $21 \%$ & $14 \%$ & $7 \%=100 \%$ \\
& $33 \%$ & $19 \%$ & $34 \%$ & $5 \%$ & $23 \%=114 \%$ \\
\cline { 2 - 6 } $\begin{array}{l}\text { Share of total } \\
\text { population, 1960 }\end{array}$ & $40 \%$ & $50 \%$ & $19 \%$ & $30 \%$ \\
\hline
\end{tabular}

Table 4: Are you in Favour of Introducing a Ghanaian National Language?

\begin{tabular}{lccccc} 
& Twi/Akan & Fante & Ga & Ewe & 12 others \\
\cline { 2 - 6 } Yes & $80 \%$ & $65 \%$ & $41 \%$ & $56 \%$ & $79 \%$ \\
No & $20 \%$ & $35 \%$ & $59 \%$ & $44 \%$ & $21 \%$ \\
\hline
\end{tabular}

Half of the civil servants interviewed had studied, $28 \%$ abroad (mostly in Englishspeaking countries), (another $13 \%$ had been trained locally, but not at university). $1 / 3$ of the interviewees visited foreign countries for purposes of tourism, sports, for personal and official reasons (2,3 travels on the average). About $80 \%$ stated that they received information from foreign broadcasting services (particularly from the BBC and the Voice of America) and foreign newspapers (mostly English and US news magazines) and that they discussed politics with their friends. Anyway, another $46 \%$ asserted that they obtained information from occasionally reading scientific books and articles in journals, but only $33 \%$ could name a title. 


\section{ASSESSMENT OF THE MAIN PROBLEMS OF THE COUNTRY}

The majority of the civil servants interviewed find in the single aspects of the economic external relations (monoculture, debts, scarcity of foreign currency, smuggling, absence of markets, decreasing terms-of-trade, etc.) the important economic problem of the country. In the number of statement there follows the problem of unemployment $(39 \%)$, of the unsatisfactory situation of rural development and the scarcity of foodstuffs $(27 \%)$, the lack of qualified cadres $(16 \%)$, and, finally, the lack of capital in general $(25 \%)$.

With unemployment (about 200.000 unemployed according to the latest assessment) and the problem of balance of payments in particular, the most acute sectors are taken into consideration. Specially for the simple consumer in Ghana, who has no further analytical capabilities, the latter can be greatly experienced individually by the repeated scarcity of consumer goods and price increase - not to speak of the lasting charges (on account of the lack of raw materials and spare parts) for the productive sector. But not lastly have the falls in world market prices which occur periodically for the main export product, cocoa, contributed indirectly, at least in three cases $(1961,1966,1972)$ to a change of the political system in Ghana.

Table 5: "What do you consider to be the most important economic problems facing Ghana?"

1. Economic external relations

$52 \%$

trade structure/monoculture

$24 \%$

balance of payment problems

$20 \%$ debts

$12 \%$

2. Unemployment

3. Agriculture/scarcity of foodstuffs

$39 \%$

$27 \%$

4. Lack of cadres and entrepreneurs

$26 \%$

5. Lack of capital

$25 \%$

6. Unsatisfactory situation of industrialization

$18 \%$

7. Material infrastructure

$18 \%$

8. Government policy

$17 \%$

9. Social infrastructure

$16 \%$

10. Personal "wrong attitude"

$16 \%$

(Open answers; several statements possible; statement of problems in percentage of all interviewees)

The insignificant analytical grasp of the problem of the balance of payments by a number of the interviewees (more than 17\%) points to the fact that these are aware of this problem as one they can actually be faced with, but not as an obstacle to the economic development in the future. Here, in fact, there are not even signs of success-promising approaches; neither in the diversification of export, nor in the stabilization of cocoa returns, the opening up of new markets, nor even in the refund of debts. Hence, the majority of those who consider the 
single aspects of economic external relations as an obstacle to the economic development, perceive, not with an altogether unjustified pessimism, that the solution to this problem is still a good way off. There is more optimism in the hope that the lack of qualified technical, administrative and entrepreneurial cadres will be removed (in 5 to 15 years). Quite an important number is rather self-critical (or critical towards "the others") and name squandermania, laziness, dishonesty and corruption as problems $(16 \%)$ and obstacles $(33 \%$. The single aspects of government policy (particularly lack of planning, waste, false taxes etc. $17 \%$ and $26 \%$ ) also meet with criticism. In both cases, however, there is neither resolution, nor unanimity in wanting to remove these grievances.

Table 6: "What do you think are the main obstacle to economic development in Ghana? State the time needed to overcome them".

\begin{tabular}{|c|c|c|c|c|c|c|}
\hline & \multicolumn{6}{|c|}{ Time needed to overcome } \\
\hline & $\begin{array}{c}\text { No. of } \\
\text { state- } \\
\text { ments }\end{array}$ & $\begin{array}{c}0 \% \text { of } \\
\text { inter- } \\
\text { viewees }\end{array}$ & $\begin{array}{l}\text { up to } \\
5 \text { years }\end{array}$ & $\begin{array}{l}5-15 \\
\text { years }\end{array}$ & $\begin{array}{c}\text { more } \\
\text { than } \\
15 \text { years }\end{array}$ & $\begin{array}{c}\text { no } \\
\text { state- } \\
\text { ment }\end{array}$ \\
\hline 1. Lack of cadres & 91 & 39 & 12 & 63 & 13 & 3 \\
\hline 2. Economic dependence & 85 & 35 & 8 & 21 & 52 & 4 \\
\hline 3. Own attitude & 80 & 33 & 21 & 20 & 28 & 11 \\
\hline 4. Lack of capital & 79 & 33 & 7 & 36 & 31 & 5 \\
\hline 5. Government policy & 58 & 26 & 10 & 13 & 24 & 11 \\
\hline 6. Social infrastructure & 31 & 13 & 1 & 18 & 9 & 3 \\
\hline 7. Material infrastructure & 25 & 10 & 7 & 15 & 3 & - \\
\hline 8. Agriculture & 21 & 9 & 2 & 14 & 5 & - \\
\hline 9. Insignificant productivity & y 21 & 9 & 7 & 9 & 2 & 3 \\
\hline 10. Other & 120 & 9 & 14 & 54 & 46 & 6 \\
\hline No. of statements & 611 & 216 & 92 & 274 & 200 & 45 \\
\hline
\end{tabular}

Open answers, several statements possible

On the other hand, as regards the method of development to be pursued, a relatively great consensus is prevalent. $3 / 4$ prefer the capitalistic way of development, but partly under different "labels". Only $29 \%$ are also prepared to call it by name. The others were obviously prevented from doing so by the wrong impression that capitalism could only be the "laissez-faire" one of the 19th century in Europe - to which they object. It is obviously unknown that the form of economy prevailing at present in all capitalistic industrial countries (call it "late capitalism" or "social market economy", as you like), besides capitalistic methods of production and market economy, also experiences farreaching governmental interventions in the economic life such as governmental social and infrastructural policy and even disposition of productive sectors etc. One would like to see all this in Ghana (and sees it already in the framework of possibilities) but defines it as "combination of socialism and capitalism", as "welfare nation" (as the NLC system and the Busia government were ideologized) or, more simply, as "democracy". But it is still astounding that almost $1 / 4$ 
declared their faith in a "socialistic development course" although the Nkrumah period (1951-1966) passed for "socialistic" and was the object of a violent counter-propaganda (from 1966 to 1972) on the part of the government (NLC, Busia). The realization of the "greatest possible equity" is attributed in the first place to a "socialistic development course". On the whole, this argument was most commonly named in the second place $(29 \%)$ after the development of private initiative etc. $(37 \%)$.

\section{THE ASSESSMENT OF THE PREVALLING EXTERNAL RELATIONS}

The present relations with almost all countries are assessed as being mostly positive (for Ghana "helpful" and "very helpful"), ( $87 \%$ of all single statements). This is based mainly on the allocation of development aid and on commerce. This estimation, however, is in contradiction with the statements concerning the questions of Tables 5 and 6 , in which single aspects of the economic external relations were assessed as being negative for Ghana by $52 \%$ and $35 \%$ respectively. This discrepancy might have several causes. It might be based on courtesy towards other ("friendly") countries and particularly on the convention in the press and in parliament, not to say anything discriminatory about their governments. But it might also show the insufficient analytical consideration, i. e., beyond the problems which can be met with, the causes and instigators are not recognized. But it is perhaps believed that the causes of the shortcomings are not to be found exclusively in Ghana or else they are attributed to a "mechanism" for which nobody is responsible or to "fate". Otherwise, how can it be that the low prices for cocoa (in Tables 5 and 6) are assessed as negative, whereas the main cocoa purchasers as such are assessed as positive? On the whole, the number of references per country tallies with the specific importance of commerce and of development policy for Ghana. Only the relations with West African countries ("smuggling"), with the Soviet Union and the EEC ("preferences" against Ghana) are assessed as negative by greater minorities. 
Table 7: "Which general method of socio-economic development do you consider to be most suitable for Ghana?"

\begin{tabular}{|c|c|c|c|c|c|c|c|}
\hline method: - & 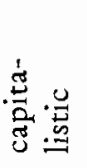 & 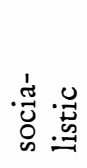 & 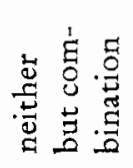 & 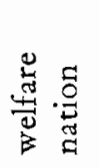 & $\begin{array}{l}\stackrel{1}{0} \\
\stackrel{0}{g} \\
\stackrel{0}{0}\end{array}$ & 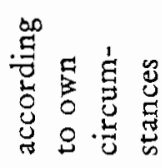 & $\frac{\text { 蓄 }}{5}$ \\
\hline & 70 & 54 & 62 & 22 & 13 & 12 & 237 \\
\hline & $30 \%$ & $23 \%$ & $26 \%$ & $9 \%$ & $5 \%$ & $5 \%$ & $100 \%$ \\
\hline
\end{tabular}

State the advantages connected with this method!*

Advantages:

\begin{tabular}{|c|c|c|c|c|c|c|c|}
\hline $\begin{array}{l}\text { 1. Development of } \\
\text { private initiative, } \\
\text { competition }\end{array}$ & 68 & 6 & 10 & 4 & 1 & 1 & $90(39 \% \text { \% })^{* * * *}$ \\
\hline $\begin{array}{l}\text { 2. "Greatest possible } \\
\text { equity" (equal dis- } \\
\text { tribution, equal } \\
\text { opportunities) }\end{array}$ & 2 & 44 & 16 & 9 & 2 & 2 & $75(32 \%)$ \\
\hline $\begin{array}{l}\text { 3. Freedom, political } \\
\text { participation }\end{array}$ & 8 & 2 & 10 & 5 & 12 & 1 & $38(17 \%)$ \\
\hline $\begin{array}{l}\text { 4. Tradition, experi- } \\
\text { ence of the past }\end{array}$ & 7 & 4 & 13 & - & 1 & 7 & $32(15 \%)$ \\
\hline 5. Govt. social services & s 1 & 6 & 5 & 9 & 1 & - & $22(9 \%)$ \\
\hline $\begin{array}{l}\text { 6. Systemical develop- } \\
\text { ment of the country } \\
\text { by the government, } \\
\text { utilization of all } \\
\text { resources }\end{array}$ & $\begin{array}{l}y \\
1\end{array}$ & 12 & 5 & 2 & - & - & $20(8 \%)$ \\
\hline 7. Other & 23 & 7 & 35 & 6 & 1 & 4 & $76(-)$ \\
\hline
\end{tabular}

* open question, several statements possible

$\because$ no answers: 4

$\% *$ percentages of all interviewees (937) 
Table 8: "Which country or group of countries do you think affect most economic development in Ghana?"**

\begin{tabular}{|c|c|c|c|c|c|c|}
\hline & \multirow{2}{*}{$\begin{array}{l}\text { very } \\
\text { helpful/ } \\
\text { helpful }\end{array}$} & \multirow{2}{*}{$\begin{array}{c}\text { detrimental/ } \\
\text { very } \\
\text { detrimental }\end{array}$} & \multirow[t]{2}{*}{ together } & \multicolumn{2}{|c|}{$\begin{array}{c}\text { External trade } \\
1969\end{array}$} & \multirow{2}{*}{$\begin{array}{c}\text { Develop- } \\
\text { ment aid } \\
57-68\end{array}$} \\
\hline & & & & Export & Import & \\
\hline England & $173(85 \%)$ & $29(15 \%)$ & $202(100 \%)$ & $106 \mathrm{~m} \$$ & $102 \mathrm{~m} \$$ & $27 \mathrm{~m} \$$ \\
\hline USA & $181(90 \%)$ & $19(10 \%)$ & $200(100 \%)$ & 65 & 47 & 247 \\
\hline $\begin{array}{l}\text { Fed. Rep. of } \\
\text { Germany }\end{array}$ & $118(94 \%)$ & $7(6 \%)$ & $125(100 \%)$ & 38 & 33 & 40 \\
\hline Canada & $56(100 \%)$ & $-(0 \%)$ & $56(100 \%)$ & 7 & 4 & 15 \\
\hline USSR & $20(57 \% / 0)$ & $15(43 \%)$ & $35(100 \%)$ & 13 & 4 & 89 \\
\hline Japan & $27\left(87^{\circ} / 0\right)$ & $4(13 \%)$ & $31(100 \%)$ & 21 & 26 & 6 \\
\hline France & $26(90 \%)$ & $3(10 \%)$ & $29(100 \%)$ & 9 & 4 & - \\
\hline EEC & $17(74 \%)$ & $6(26 \%)$ & $23(100 \%)$ & 74 & 89 & - \\
\hline $\begin{array}{l}\text { West-African } \\
\text { countries }\end{array}$ & $12(54 \%)$ & $11\left(46^{\circ} / 0\right)$ & $23(100 \%)$ & 3,2 & 0,08 & - \\
\hline Other & $56(83 \%)$ & $11(17 \%)$ & $67(100 \%)$ & 64 & 60 & \\
\hline $\begin{array}{l}\text { No. of } \\
\text { statements }\end{array}$ & $684(87 \%)$ & $105(13 \%)$ & $789(100 \%)$ & 354 & 333 & \\
\hline
\end{tabular}

$\because$ statement of several countries possible

The purposive questions about the importance of the experts of technical and development aid in general are also positively assessed by similarly large majorities $(89 \% \text { and } 86 \%)^{2}$.

Even the negative opinions are obviously founded, not on basic considerations, but rather on the specific from as well as on particular events and experiences.

Table 9: "Do you think that the role of technical assistance experts is ...?"

\begin{tabular}{lccccc}
\hline & $\begin{array}{c}\text { very } \\
\text { helpful }\end{array}$ & helpful & $\begin{array}{c}\text { un- } \\
\text { helpful }\end{array}$ & $\begin{array}{c}\text { detri- } \\
\text { mental }\end{array}$ & $\begin{array}{c}\text { positive } \\
\text { negative }\end{array}$ \\
\hline $\begin{array}{l}\text { all respondents } \\
\begin{array}{l}\text { respondents working } \\
\text { with experts }\end{array}\end{array}$ & 126 & 87 & 16 & 10 & $89: 11$ \\
\hline
\end{tabular}

2 These results are in contradiction with many public statements in Ghana. Thus, the 7 th Annual Congress of Ghana Science Association criticized the excessive dependence of the government on foreign experts for nationalplanning. The influential intellectual newspaper "Legon Observer" wanted to attribute a series of economic mistakes particularly to the influence of foreign advisers and, therefore, demanded that these be "politely requested" to leave the country (Vol. VI, 27, Dec. 71). 
Table 10: "Do you think that development aid has had a positive impact on the economy of Ghana in recent years?"

\begin{tabular}{ccc}
\hline Yes & No & no answer \\
$204(86 \%)$ & 28 & 6 \\
\hline
\end{tabular}

On the other hand, far greater scepticism is shown towards foreign private investments. More than 2/3 find therein advantages and disadvantages for Ghana; however, only a small minority $(5 \%)$ do not find therein any advantages at all for Ghana.

The supply of investment capital and foreign currency $(39 \%)$ in the first place, the procurement of places of work $(30 \%)$, the teaching and training of Ghanaians as well as the demonstration effect in general $(26 \%)$ are mentioned as advantages. As disadvantages count the considerable losses through the drain of profit $(26 \%)$, the perception that foreign investors always set their own interests above Ghana's and, in different ways, even "exploit" $(17 \%)$ the country and their monopolization of the economy and hindrance to the development of the Ghanaian private economy $(11 \%)$.

The suggestions as to how the "disadvantages" mentioned can be removed, show, however, that a considerable number of interviewees assess wrongly the scope, character, origin and objectives of private foreign investments, confound them simply with other phenomena, and, therefore, try to make them more useful for Ghana for silly (ask the foreigners to be less egoistic) or unrealistic measures. Thus, a series of governmental regulatory, compulsory and restrictive measures are suggested (which, for the most, are actually enforced), without the fact becoming obvious that these measures would restrict the probability or, at least, the scope of foreign private investments in Ghana to a considerable extent (whereby the positive characteristics attributed to them would be lost). In fact, important foreign investments are few (in Ghana since independence). Most of the foreign enterprise made their original investments already in the colonial period and expanded their profits by (sometimes compulsory) re-investments. The actual influx of foreign currency and of capital as well as the employment effects (the number of persons employed in the private sector remained almost stagnant in the last decade) thus seemed to be considerably overestimated.

Table 11: "Do you think that the activities of European and American businessmen in Ghana are in the interests of the economic and social development of Ghana?”

\begin{tabular}{cccc}
\hline no answer & are in the interests & are not... & are partly ... \\
$6(2 \%)$ & $86(36 \%)$ & $12(5 \%)$ & $136(57 \%)$ \\
\hline
\end{tabular}


Table 12: "What do you consider to be particularly advantageous and/or disadvantageous in the activities of these businessmen?" "*

\begin{tabular}{lcccc}
\hline $\begin{array}{l}\text { Attitude towards } \\
\text { foreign investments: }\end{array}$ & positive & negative & mixed & together \\
\hline $\begin{array}{l}\text { They bring investment } \\
\text { capital and foreign currency }\end{array}$ & 52 & - & 38 & $90(38 \%) \%$ \\
$\begin{array}{l}\text { They reduce unemployment } \\
\text { Training of Ghanaians }\end{array}$ & 23 & 1 & 47 & $71(30 \%)$ \\
$\begin{array}{l}\text { Demonstration effect, } \\
\text { bring technology and know-how }\end{array}$ & 23 & - & 40 & $63(26 \%)$ \\
$\begin{array}{l}\text { Other positive arguments } \\
\begin{array}{l}\text { Drain of profit, loss of } \\
\text { foreign currency }\end{array}\end{array}$ & 23 & - & 11 & $28(12 \%)$ \\
$\begin{array}{l}\text { Always put their interests first, } \\
\text { exploit }\end{array}$ & 8 & 4 & 10 & $33(13 \%)$ \\
$\begin{array}{l}\text { Monopolization of economy, } \\
\text { hinder Ghanaian private economy }\end{array}$ & 4 & 3 & 36 & $40(17 \%)$ \\
Other negative arguments & 8 & 5 & 18 & $26(11 \%)$ \\
\hline No. of statements & 159 & 17 & 281 & 457 \\
\hline
\end{tabular}

* open answers, several statements possible

$*$ no of statement as percent of all respondents 
Table 13: "How can these disadvantages be overcome?"*

\begin{tabular}{|c|c|c|c|c|}
\hline $\begin{array}{l}\text { Attitude towards } \\
\text { foreign investment }\end{array}$ & positive & negative & mixed & total \\
\hline $\begin{array}{l}\text { No. Statements concerning } \\
\text { measures }\end{array}$ & 61 & 1 & 25 & $87(38 \% \text { \% })^{* \%}$ \\
\hline $\begin{array}{l}\text { Incentives and aid for local } \\
\text { entrepreneurs / limitation } \\
\text { of sectors for foreigners }\end{array}$ & 8 & 3 & 28 & $39(16 \%)$ \\
\hline $\begin{array}{l}\text { Govt. should prepare investment } \\
\text { agreements more carefully / } \\
\text { exercise stricter control }\end{array}$ & 6 & 1 & 24 & $31(13 \%)$ \\
\hline $\begin{array}{l}\text { Govt. should force foreign } \\
\text { enterprises to train more } \\
\text { Ghanaians and to employ them } \\
\text { in leading positions }\end{array}$ & 7 & 1 & 16 & $24\left(10^{\circ} / 0\right)$ \\
\hline Limitation of profit transfer & 3 & - & 20 & $23(10 \%)$ \\
\hline Other & 17 & 8 & 55 & 80 \\
\hline No. of statements & 41 & 13 & 143 & 197 \\
\hline
\end{tabular}

* open answers, several statements possible

$\%$ No. of statements on percent of all respondents

\section{THE PLANNING OF FUTURE RELATIONS}

The improvement and intensification of relations with other nations are greatly encouraged. $63 \%$ are in favour of an association with the EEC, mainly in the hope of increasing the exports to these countries. A minority $(7 \%)$ sees in the association with the EEC an obstacle to the intensified pan-African cooperation and integration, of which a total of $85 \%$ declare themselves in favour. Whereas, in the last years, Ghana had only been considering and "testing" passively an association in the late conflict-loaded Nkrumah period, since 1966, the country has been undertaking active efforts to intensify and extend its relations to West African countries at multilateral (in an economic community) and bilateral level. 
Table 14: "Are you in favour of improving the economic cooperation with the EEC, other African and non-African countries?"

\begin{tabular}{|c|c|c|c|}
\hline & Yes & No & No opinion \\
\hline EEC & $152(63 \%)$ & 67 & 16 \\
\hline African countries & $201(85 \%)$ & 26 & 7 \\
\hline $\begin{array}{l}\text { Other countries } \\
\text { among which: }\end{array}$ & $125(52 \%)$ & 65 & 20 \\
\hline USA & $45(19 \%)$ & $\begin{array}{l}\text { Socialist } \\
\text { countries }\end{array}$ & $24(10 \%)$ \\
\hline England & $43(18 \%)$ & Canada & $23(10 \%)$ \\
\hline Japan & $43(18)$ & Israel & $26(11 \%)$ \\
\hline Fed. Republic of Germany & $33(14)$ & Other & 48 \\
\hline
\end{tabular}

But beyond the settlement of border quarrels, the opening of the borders and the (relatively insignificant) improvement of transnational communications, decisive success in the sectors which really matter, trade expansion, "cultural exchange", joint development planning, joint management of common services (communication, research), are not evident.

Table 15: "Do you consider that an association between Ghana and the European Economic Community (EEC) is helpful for Ghana? Please explain your choice".

\begin{tabular}{cc} 
is desirable & is not desirable \\
$152(63 \%)$ & $67(29 \%)$ \\
\hline
\end{tabular}

1. New markets, removal of discriminatory prefence

2. ... if England joins EEC, so must we

3. To receive development aid

4. Other positive reasons

5. Instead we need (at first) more pan-African cooperation

6. EEC is more in the interest of the 'Great Six'

7. We are not equal, cannot compete, neo-colonialism

8. Ghana would remain supplier of raw materials, would not open up new markets

In this connection, it is interesting to note wherein the main obstacles and difficulties are to be found, should there be an expansion of the pan-African cooperation or even integration: the most common dificulties are the language ones (English/French), (37\%), followed by the other political and economic structures differently marked by colonialism as well as by the still actual 
dependence on various (formerly colonial) metropoles $(23 \%)$, but also distrust, jealousies and selfishness of the African countries among themselves $(21 \%)$.

As concerns the last point, another reason, which is usually not given, is also entered upon: the incapacity to arrive at a give and take compromise. Thus, particularly in Ghana, after the generous wastefulness under Nkrumah, there prevails an almost traumatic conception of giving more than taking if there is an African cooperation. This is why only $22 \%$ give a positive answer to the question as to whether they would be prepared to give up Ghana's sovereignty in certain sectors for African cooperation.

Table 16: "What do you consider to be the main obstacle to such cooperation?" (with other African countries)*

Language problems (English/French)

$74(37 \%) * \%$

Different economic and political structures as heritage of

colonialism, dependence on various metropoles

$42(21 \%)$

Distrust, jealousies, selfishness

$46(23 \%)$

Political and ideological differences

$40(20 \%)$

Different currencies, economic policy, trade barriers and

trade problems

$39(19 \%)$

Lacking transnational communications

$35(17 \%)$

Different political systems, instability

$30(15 \%)$

Artificial borders

$20(10 \%)$

General underdevelopment, different resources and development

$16(8 \%)$

Total number of statements

342

* open answers, several statements possible

$*$ percent of number of respondents (201)

The approval and, thus, support of radical solutions - in whatever direction is hardly to be expected from the Ghanaian civil services. It sticks much more to the prevailing structures, tries to come to terms with them, to intensify and improve them and to expand them positively for Ghana. The world image is often rather ingenious and the solutions suggested for acknowledged problems are rarely ingenious and reasoned. This is moreover obviously based on a considerable over-assessment of the own importance and possibilities.

Table 17: "How important do you consider Ghana's role to be in the field of international relations?"

\begin{tabular}{lrrrr}
\hline & $\begin{array}{c}\text { very } \\
\text { influential }\end{array}$ & influential & $\begin{array}{c}\text { moderately } \\
\text { influential }\end{array}$ & $\begin{array}{c}\text { without } \\
\text { influence }\end{array}$ \\
\cline { 2 - 5 } in world politics & $18(8 \%)$ & $66(27 \%)$ & $125(52 \%)$ & $22(9 \%)$ \\
in African politics & $108(45 \%)$ & $69(29 \%)$ & $45(19 \%)$ & $11(5 \%)$ \\
\hline
\end{tabular}


where the growth of formal, foreign system of norms and values are subverted and retarded by premordial types, to that of "Fusional dualism" where the formal elements will begin to gain the upper hand in influencing actual behaviour. One strategy which this essay considers as a highly plausible approach toward this objective is identified under the concept of the "Desiderative Constitution", which is formulated as a codification of formal definitions of institutions and norms explicitly designed to engender orientations whose net effects will tend to curb those manifestations of tradition that exert a dysfunctional impact on the emergence of modernizing forces while at the same time reinforcing and striking deep roots in the benign hereditary milieu.

\section{The Political Image of Ghanaian Civil Servants}

\section{By Rolf Hanisch}

In African countries, the civil service represents a social class of considerable importance which surpasses by far its numerical strength. The success of the Politicians' policy depends largely on its efficiency and its subjective consciousness of wanting to prepare and implement a certain policy. In the context of their societies, the civil servants represent most of ten a socially privileged group, which has considerable group interests to defend and which has, therefore, the reputation of being not particularly innovatory in their attitude.

This paper tries to gather some empirical data on the political image of civil servants in Ghana on the basis of 237 questionnaires. The core of the series of problems concerned were the economic and development problems and prospects of the country under particular consideration of international relations. If this sample is representative, the approval and, thus, support of radical solutions in whatever direction - is hardly to be expected from the majority of the Ghanaian civil service. It sticks much more to the prevailing structures, tries to come to terms with them, to intensify and improve them and to expand them positively for Ghana. The world image is often rather ingenious and the solutions suggested for acknowledged problems are rarely ingenious and reasoned. This is moreover obviously based on a considerable over-assessment of the importance and possibilities of Ghana in the world.

\section{Mexico's Establishing of the Exclusive Economic Zone to its Coasts}

\section{By Gerhard Scheffler}

From the beginning, Mexico was one of the first states claiming the exclusive economic zone. The setting up of this zone by Mexico in July 31, 1976 remains in the recent development of this matter: One month after US-President Harry S. Truman's Proclamation on the continental shelf Mexico claimed the shelf before its coasts. In 1972 the Afro-Asiatic countries demanded the body of sea, therein coastal state would have special jurisdiction to explore and exploit for its own benefit the marine resources and those of the seabed and subsoil of the 